\title{
金型成形におけるトラブルと対策
}

\author{
水 本 清 文
}

\section{Troubles and Measures in the Rubber Moulding}

Kiyofumi MIZUMOTO(Nagashima Packing Seisakusho Co.,Ltd., 4-3-9 Koyama, Shinagawa-ku, Tokyo 142-0062, Japan)

Troubles mean the generation of defective products in the compression moulding. The generation of defective products is considered to result from the flow and the scorch characteristics of mixed compound. These characteristics are dependent on processing temperatures. Watching the flow state when mixed compound goes into mould cavities is important. Other causes, such as parallel accuracy and distribution of temperature of platens, staining of mould, are related to defective products. This paper considers the causes and measures against defective products.

Key Words : Compression Moulding, Defective Product, Flow Mark, Weld Mark, Backrind, Mould

\section{1.は じめ に}

金型成形は，製品となる金型キャビティに練りゴムを流 し达み充てんして加硫する。したがって，キャビティ内に 空気や発生ガスが残存しては困るので, 練りゴムの流入圧 カでこれらを排除できる金型構造が望まれる.練りゴムは, 加硫温度に加温された金型に接触して流れるので，穴の条 件のもとで適切な流動性を発揮する状態のものが好まし い. 金型のキャビティ側の表面は，練りゴムの流れを阻害 しないことや加硫後に製品の離型性のよいことが要求され る.このように金型成形では金型構造と練りゴムの流動性 が成形加工の要点となる．練りゴムは，製品の機能を優先 とするので加工性が多少困難な場合もある。成形方法は圧 縮成形，注入成形，射出成形があるが，多数個取り金型が 多く用いられる压縮成形を中心に製造現場で発生する不良 問題について原因を考え，解決の糸口を見つけることにす る.

\section{2. 金型成形における不良問題11}

\section{1 外観不良}

成形品は外観に生じる欠点部分から原因となることが推 定され，その原因を取り除くことが対策となる．外観の問 題について表 1 のようにまとめ, 種別に原因を考えてみる.

\section{1 .1 表面の状態}

表面状態は金型表面の転写である。転写不良は練りゴム のスコーチが原因のことが多い. 練りゴムのスコーチは保 管状態や経時変化の影響を受け，高温金型中の流動時に起
こることが多い. 現象として縮れたような肌荒れ状態が見 られる. また, 図1のように表面は平滑なのに円形などの つやの異なる表面が生じることがある。原因として離型性 が考えられ，ガス発生の多い配合や高充てん配合の練りゴ ムに発生することが多い. 離型剤の塗布の均一化, 加硫後 の成形品取り出しを早くすることが対策となる.

\section{1 .2 ベア}

成形品の表面に生じた図 2 のようなくぼみで，エア抜き

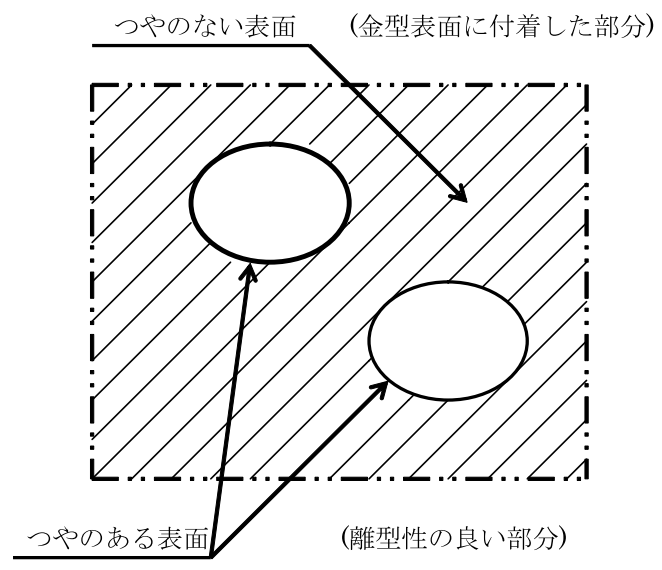

図 1 表面にできた模様 11

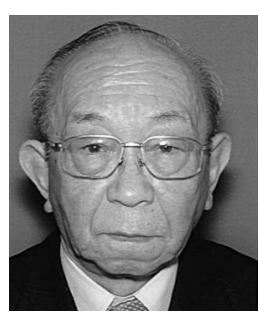

水本 清文; 株)永島パッキング製作所 ( 0062 東京都品川区小山 4-3-9) 技術顧問. 昭 和 35 年, 日本大学理工学部工業化学科卒業. 三興護謨工業(侏在職. 平成 2 年より現職. 専 門は，ゴム製品製造技術．ゴム協会評議員. 
表 1 外観の問題 ${ }^{1}$

\begin{tabular}{|c|c|c|}
\hline 題 & 内 & 原因と考えられること \\
\hline \multirow{2}{*}{$\begin{array}{l}\text { 1.表面の状態 } \\
\text { (金型表面の転写不良) }\end{array}$} & (1) 肌荒れ状態 & 練りゴムのスコーチ \\
\hline & (2) 模様の発現 & 金型への部分的付着 \\
\hline 2. ベア & 表面の局部的くぼみ & $\begin{array}{l}\text { ·練りゴムの粘着過多 } \\
\text { ·局部的成形圧力の不足 } \\
\text { ・キャビテイ内のガス残存 } \\
\text { •充てん量の不足 (練りゴムの流動性過剩による型外流失) }\end{array}$ \\
\hline \multirow[t]{2}{*}{ 3. 表面の微細な凹凸 } & 微細なくぼみ & 熱溶融物質の分散不良 \\
\hline & 微小な突起やふくれ & $\begin{array}{l}\text { ・異物・異材の混入 } \\
\cdot \text { 充てん剂などの吸湿 } \\
\text { ・練りゴム中の気泡 }\end{array}$ \\
\hline 4.フローマーク & 線状あるいはクラック状のきず & 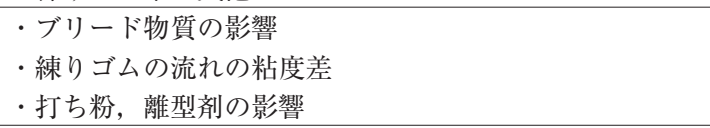 \\
\hline 5. 融合部の不良 & 割れ，裂け，きず & $\begin{array}{l}\text { ・練りゴムの流れ性不良 } \\
\text { ·金型の污れ } \\
\text { ·流動中のスコーチ } \\
\text { •練りゴムの熱履歴によるコーチ時間の短縮 } \\
\cdot \text { ブリード, ブルームの影響 } \\
\text { ·離型剂の影響 }\end{array}$ \\
\hline 6. バックラインド & ばり部分に生じる凹み状の表面破壊 & $\begin{array}{l}\text { ·熱伝導による表面と内部の温度差 } \\
\text { • 加硫温度の高過ぎ }(\text { 不適 }) \\
\text { ·加硫速度の速過ぎ }\end{array}$ \\
\hline
\end{tabular}

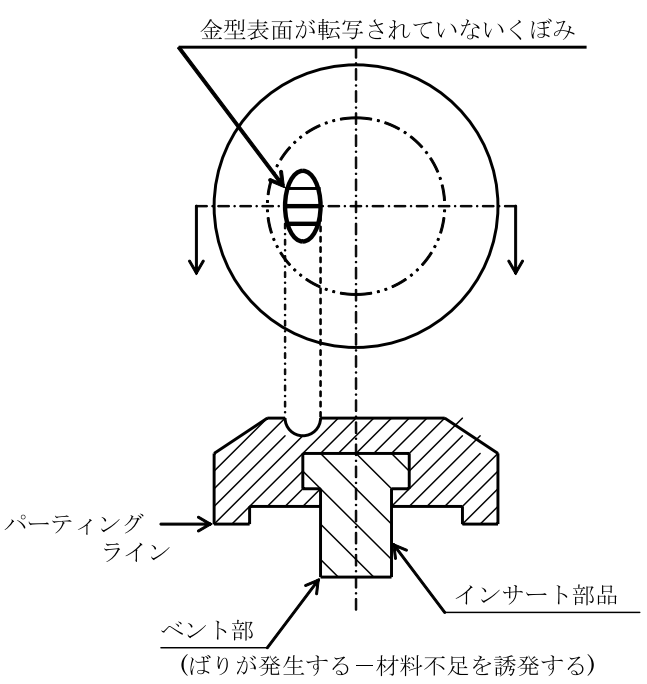

図 2 ベアの例1)

不良，充てん量の不足が原因と考元られる。エア抜きは練 りゴムの弾性と気体の膨張を利用するので，練りゴムが金 型表面に粘着するような低粘度となると効果はない。一方， キャビティへの充てん量不足は, 練りゴムの流動性が過剩 となり必要とするキャビティ空間以外に流失することが原 因となる．離型剤の塗布の均一化と加圧速度の減速などが 対策として考えられる。

\section{1 .3 表面の微細な凹凸}

微細なくぼみの場合は加硫温度以下で溶融する配合剤の 分散不良が原因と考えられるので，練りゴムをストレーナ あるいは薄通しなどで分散不良の物質を除去する。その場 合，練りゴムの粘度が低下し加硫特性も変わることがある ので注意する。また，微細なふくれの場合は異材，異物の 混入のこともあり混練工程の材料替えが原因と考えられ

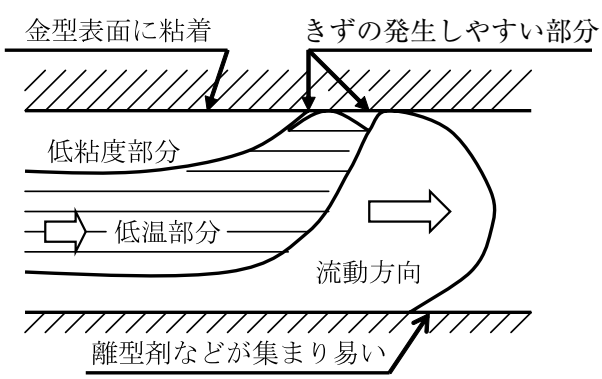

図 3 フローマークの例

る。この他に，充てん剤などの吸湿，あるいは混練り機械 の過冷による結露の水分が混入すると加硫後に微細なふく れとなることがある。この場合には金型污染を起こしやす く, 配合によってはスコーチを促進し, 特性として電気絶 縁性や熱劣化に影響があるので練りゴムとしては使用しな い. 練りゴムに残存している気泡の多くは圧延時に混入す ることが多く，金型内の練りゴムの流動が大きい場合やバ ンピング(エア抜き操作)で解消される。これに対し，流動 が小さい場合にはフローマークのようなきずを生じるので 大きな気泡はつぶしておくか除外するほうが良い。

\section{1 .4 フローマーク}

フローマークは練りゴムの流れの跡が成形品表面に残つ た状態を指し，線状やクラック状のものなどがある．原因 として, 練りゴムの流れ方の問題があり, 図 3 のように加 温状態の差による粘度の差，部分的なスコーチ，金型表面 の污れによる流れの障害が考えられる，圧縮成形では金型 に仕込まれた練りゴムは金型表面に接触して加温される。 したがって，加温状態は金型接触面から内部に温度勾配を 生じているのでキャビティ内の流れが不均一になり易い. この場合の対策として, 仕込む練りゴムを予備加温するか, 
または成形時低圧である程度流動させ少し時間をおきバン ピングをしながら最終成形圧にする方法などがある，その 他の原因として練りゴムの表面にあるブリード物質, 粘着 防止としての打ち粉などが影響していることがある。ブリ ードは保管時間が長くなると起こりやすいので, 混練り後 の安全期間を設けて使用する．打ち粉と同様に離型剤の過 剰塗布もフローマークの原因となる.

\section{1 .5 融合部の不良}

融合部とは，図 4 で示すようなキャビテイ内にあるピン やコアにより練りゴムの流れが分断され再び合流する部分 を指し，この合流部に生じる傷をウエルドラインあるいは ウエルドマークと呼ぶ。この合流部分の強度が低いと破壊 の起点となり易い. 原因はエアや相溶性に乏しい物質や離 型剂の溜まりで，連続生産の初期には成形品の表面に曇り が生じる程度であるが，徐々に金型表面に堆積物が現れ金 型污れとなりきずが顕著に現れるようになる。この場合に は早めに判定し金型の洗浄を行う。また，加硫の早い練り ゴムの場合には流れの表面のスコーチということもあり， 予備成形工程 (カレンダー圧延, 押出し)の熱履歴, 保管時 間が関与し，同一練りゴムでは時間経過とともに不良率が 高くなる，対策として，離型剤の場合は塗布量を少なくす る方法あるいは焼付け型のものとする。エアの場合では練 りゴムの流れ方を考慮しながらバンピングの良いタイミン グを探す．スコーチの場合は工程で受ける熱履歴を低減す るために冷却後の積み重ねを励行する。

\section{1 .6 バックラインド}

バックラインドとは，ブロック状の肉厚製品や円筒形製 品のばり部分に生じた不規則形状の凹みで，フラッシュバ ックということもある．円筒形の製品の場合にはその内面 に傷が生じていることもある。図 5 に例を示す。原因は金 型に接触している表層と内部の加硫速度の差で, 内部の温 度が遅れて上昇するため熱膨張による内圧が高まり，表層 の加硫部分をパーティング部に押し出すようになる。その 加硫部分の流出が金型の角で破壊されるために発生する.

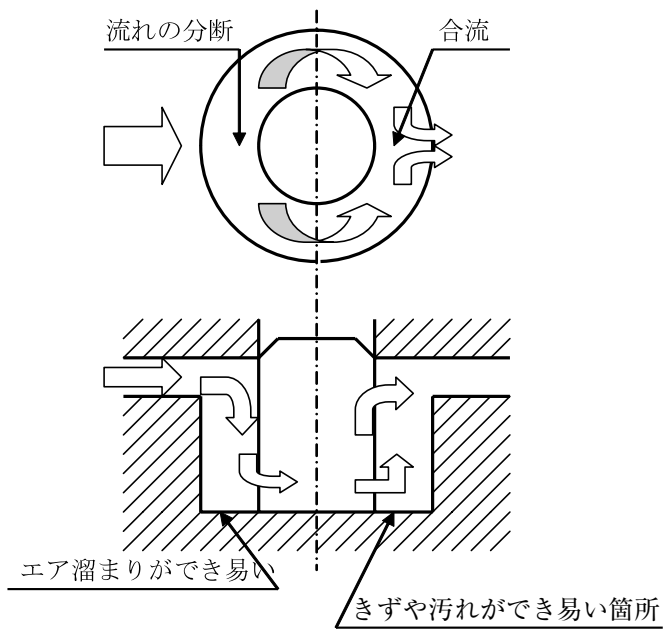

図 4 融合部の例

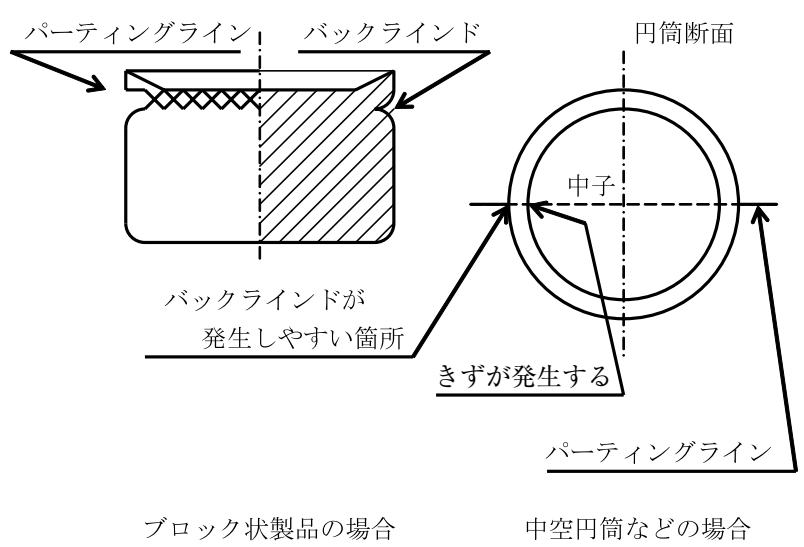

図 5 バックラインドの例1)

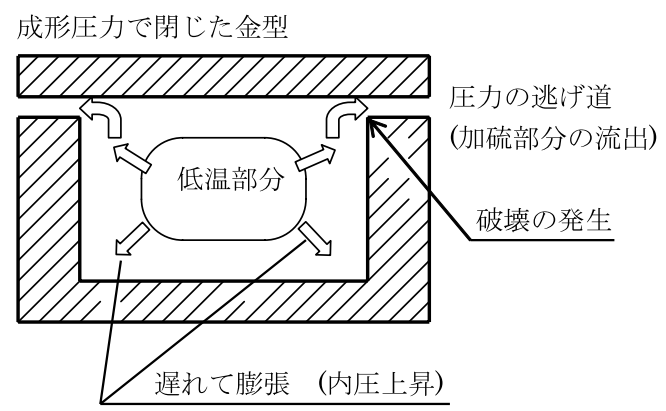

四 6 バックラインドの発生機構

これらの発生機構を図 6 に示す。円筒形の場合は中子の低 温化が原因で加硫中の昇温による熱膨張が起こるため同様 の現象となる。これらの原因から対策を考えると, 金型表 面と内部の練りゴム温度が同じになるようにすれば良い, あるいは表面と内部の加硫状態がほぼ同じに進行すれば良 いということが分かる. 練りゴムを加温してキャビティに 注入する注入成形, 射出成形では起こり難いが, 圧縮成形 では対策が十分にとれないのが現状と思われる．方法とし て，金型のばりの出る角を丸くする，中子にヒーターを設 置し温度を保つようにするなど予め対策をとっておく．そ の他，成形時に仕込む練りゴムをスコーチしない程度の高 温に加温する，金型のキャビティ表面を冷水などで冷やし 温度勾配を付けるなどが有効なことがある。

\section{2 寸法不良 ${ }^{1)}$}

\section{2 .1 厚み方向の寸法不良}

一般に練りゴムの充てん量の過不足が原因となる. 表 2 に寸法に関する問題を示す。充てん量不足の場合には計量 器の不具合ということもある。厚み方向の寸法不良はばり の厚みに依存する．金型設計の際，図 7 の例のように多目 の充てん量を吸収できる溝や枠を設定し，ばりの厚みが一 定となるような型構造とする. その他, 練りゴムのスコー チが原因で予定されている流動が得られなかったために部 分的な厚み不良が発生することがある。ばりの厚みや状態 を観測し表面異常のばりはスコーチが原因と考える.

\subsubsection{XY方向の寸法不良}

金型に仕达む練りゴムの圧延時に受けたひずみの残留が 
表 2 寸法の問題 ${ }^{1)}$

\begin{tabular}{|c|c|c|}
\hline 問 題 点 & 内 & 原因と考えられること \\
\hline \multirow[t]{2}{*}{ 1. 寸法不良 } & 厚み方向 (ばりの厚み) & $\begin{array}{l}\text { ・練りゴムのスコーチ } \\
\text { ・練りゴムの流れ性不良 } \\
\text { ·充てん量の間違え }\end{array}$ \\
\hline & $\mathrm{XY}$ 方向 & $\begin{array}{l}\text { ・練りゴムのスコーチ } \\
\text { ・圧延時の列理の影響 } \\
\text { • 加硫温度の設定変更 } \\
\text { · 成形圧力の変動 }\end{array}$ \\
\hline $\begin{array}{c}2 \text {. 多数個取り金型の } \\
\text { 部分的寸法誤差 }\end{array}$ & 位置による寸法不良 & $\begin{array}{l}\cdot \text { 金型温度の不均一 } \\
\text { ·成形圧力の不均一 } \\
\text { ·練りゴムの流れ方の影響 } \\
\cdot \text { ·金型の変形 } \\
\text { ·成形機の熱板の平行度 }\end{array}$ \\
\hline
\end{tabular}

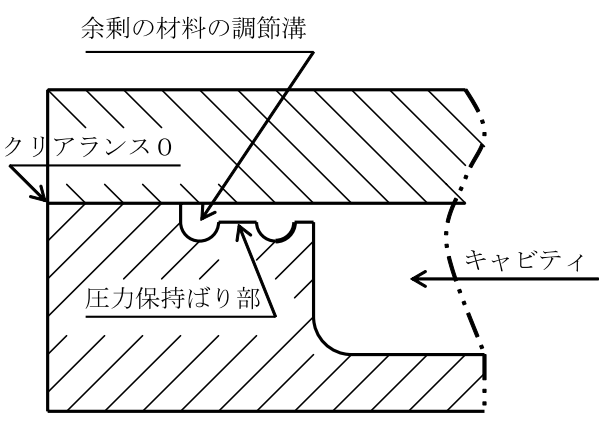

四 7 厚みを安定させる構造例

原因となる，一般的に圧延方向の収縮が大きくなる．配合 内容にもよるが，圧延方向に延伸されている状態を常温よ り少し高い温度で自由収縮させることにより残留ひずみを 除くことができる．金型内の流動中に生じたスコーチもひ ずみとなり加硫後寸法誤差を生じる。一般的に標準として いる加硫温度, 成形圧力の変更も寸法に影響し, 高温に変 更した場合や成形圧力を下げると収縮率が大きくなる傾向 がある。

\section{2 .3 多数個取り金型の場合}

金型の外周部と中央部分で寸法差が生じることがある. 原因はいろいろ考えられるが，厚み方向では熱板の平行度 の狂いと金型の変形，その他の寸法では金型内の温度分布 の不均一で外周部の放熱による温度低下が原因となる。熱 板の平行度の狂いは成形圧力の不均一となり，練りゴムの 流動にも影響する．成形圧力の不均一は金型への圧力分布 が生じることになり，圧縮荷重の偏在となり金型変形への 影響ともなる，金型内の温度分布の不均一は，金型の線剅 張の部分的変化となり，金型変形の原因ともなる．これら の対策は個々の現場で原因を探し改良することで，特に四 角い金型の四隅に注意する.

\section{3 複合材の接着の問題 ${ }^{2)}$}

成形加硫と同時に他の材料と接着する場合, 表 3 に示す ような問題が生じることがある。接着不良は被着材の表面 処理あるいは練りゴムとの接触面の問題で，加硫前の接着 処理面の清浄を維持することが対策となる．接着剂塗布後 の溶剤の残留が原因となることもある。接着強度は破壊試
表 3 複合材の接着の問題 ${ }^{2)}$

\begin{tabular}{|c|c|c|}
\hline 問＼cjkstart題 & 容 & 原因と考えられること \\
\hline \multirow[t]{2}{*}{ 接着状態の問題 } & 被着材の界面はく離 & $\begin{array}{l}\cdot \cdot \text { 被着材表面処理の不適 } \\
\cdot \text { 接着郕の不適合 } \\
\cdot \text { 接着剤の取り扱いの問題 }\end{array}$ \\
\hline & $\begin{array}{l}\text { 接着剂と加硫ゴムの } \\
\text { 界面近傍のはく離 }\end{array}$ & $\begin{array}{l}\cdot \text { 接着剂の不適合 } \\
\cdot \text { 溶剤の残存 } \\
\text { - 練りゴムの加硫速度不適 } \\
\cdot \text { 接着剤塗布面の污染 }\end{array}$ \\
\hline
\end{tabular}

験をしなければ分からないので現場では被着材の表面処理 状態，接着剤の塗布状態，乾燥保管などの管理を十分に行 う。接着剤は練りゴムの流れにより金型に付着することが あり金型污染の原因となるので，定期的に金型表面状態を 検查する，繊維織物との複合材の場合，接着剂を塗工機な どで塗布するが糸を構成する瀻維束の内部にまで接着郕を 侵入させないようにする。そのためには接着剤の固形分濃 度を高めに設定すると良い。瀻維束を接着郕や加硫ゴムで 固化させてしまうともろい状態となり複合による補強効果 が得られなくなる。また, 瀻維束は空隙があるので吸湿, 溶剤やガスが残存することが多い．外観上のふくれ現象と なることがあるので接着処理後の保管に注意する.その他, 接着する練りゴムの表面の清浄状態や接着剤との加硫速度 のバランスが重要であり, 被着金属材などの加温は練りゴ ムの流動や接着面のひずみへの影響を少なくする.

\section{3. 金 型 の 問 題 ${ }^{2)}$}

\section{1 金型の変形}

金型に関する問題を，表 4 にまとめてみた，長時間使用 した金型は成形機の熱板の状態 (平行度，摩耗)による影響 を受けている．圧縮成形の場合には投影面に対し厚み方向 の小さい板状の金型が多いので熱板の影響を受けやすい. 金型の加温をするため加硫温度の熱板に扱入し加圧した場 合，外周が加圧力で固定されていると金型の熱膨張は拘束

表 4 金型の問題 ${ }^{2)}$

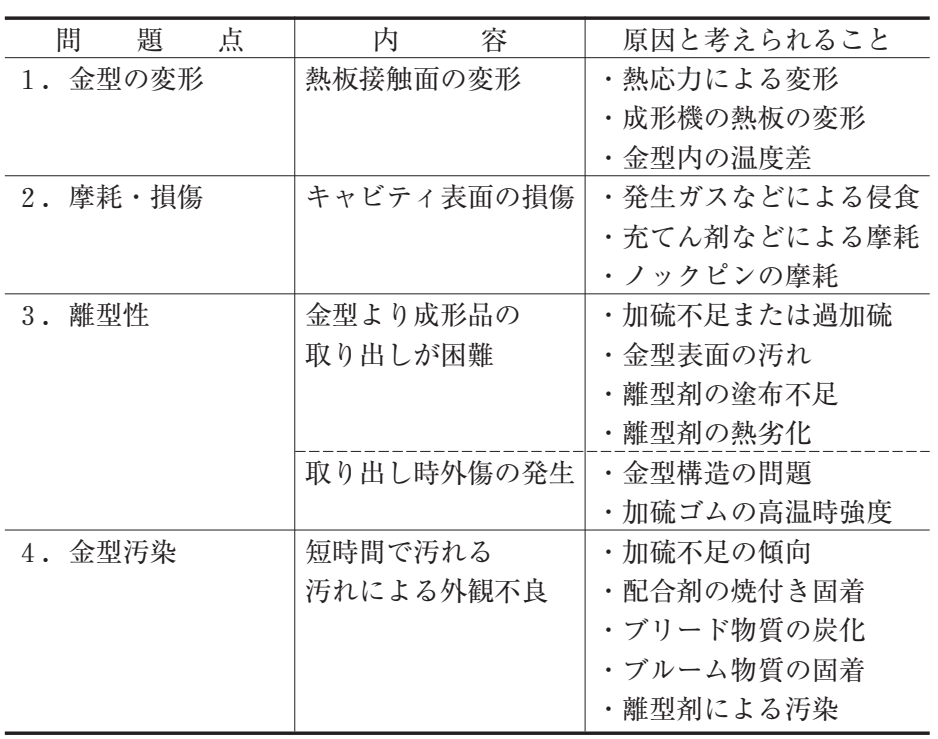



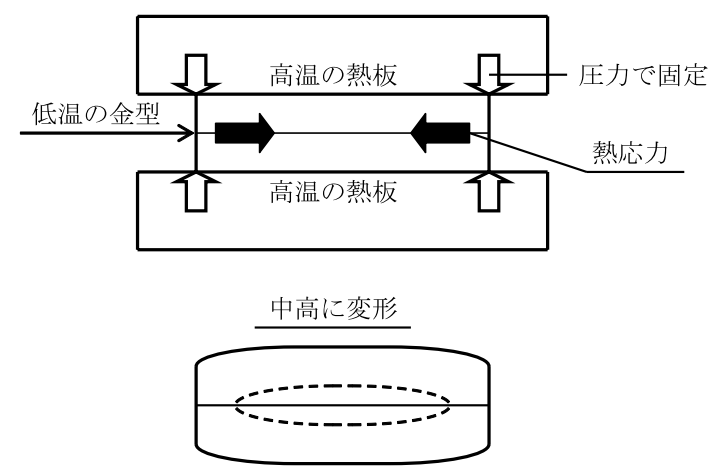

図 8 金型変形の模型図 ${ }^{2)}$

されるため熱応力が発生し，図 8 のように熱応力の影響は 金型内部へ向かい厚み方向への膨張となり，中央部の湾曲 が生じるようになる，金型を加温する場合はこの点に注意 する必要がある。また，金型の厚みが厚い場合，側面から の放熱により外周部が低温となる．熱板の熱源となるヒー ターの位置による影響もあり，熱膨張の差が金型変形に関 与する. 金型が変形し金型と熱板との接触が不十分となる と，熱の伝導が変わり金型内の温度分布が変わるという悪 循環となり，成形機の熱板平行度も狂わすということにな る。現場としての対策は以上の事柄を踏まえ影響の無いよ うにすることである。

\section{2 金型の摩耗・損傷}

金型の寿命に関連することで，使用している練りゴムの 種類や配合による。腐食性ガスなどが発生しやすい場合に は表面处理や防錆保管だけでなく使用後の洗浄が重要であ る。研磨剤のように硬い充てん剤が流動する場合や洗浄に 粒子の吹きつけを行った場合などでは部分的な摩耗が生じ る。これらはキャビティの角部分，ピンとはめ合い穴，彫 刻文字などに影響がでる。その他，ノックピンの摩耗は金 型の組み立て位置の食い違いを生じ，成形品の形状不良を 引き起こすので定期的に検査し交換する．インロー構造の テーパー部分はばりの発生や污れにより位置決め効果がな くなるので清掃を心がける。

\section{3 離型性}

金型の離型性はめっきなど表面処理で予めスムーズな作 業ができるようになされている。この離型性が悪くなると いうことは，加硫ゴムが金型表面に接着しやすくなったと 考える。これは金型の表面状態が変わったと判断され，金 型の污れが原因となる。したがって，離型性が悪くなった ら金型を洗浄して初期の状態に戻すことである。その他， 加硫ゴムの常温強度は高くても, 加硫温度における強度は 極めて低い．特に複雑な形状やアンダーカットのある場合 には，金型からの成形品の取り出し時に裂けや傷を生じ易 いので注意しなければならない。

\section{4 金型污染}

金型の污れの原因は配合内容や加硫系などの影響があり
個々に検討されることになる。一般的に充てん剤の多い練 りゴム, 吸湿した状態の練りゴムなどが金型を污しやすい。 加硫状態が不足の場合，ブリードやブルーム物質がある場 合，水系離型剂の希釈水の不純物も金型污れを早める.

\section{4. 成 形 作 業}

\section{1 成形機の問題}

成形機の熱板サイズは金型の外形寸法より最低 $30 \mathrm{~mm}$ 大きいことが必要とされている．熱板の熱源が金型外寸の 位置まであると金型の温度分布が安定する。これらについ ては図 9 を参考にして欲しい.外周に不良が多い場合には, 成形機について適正か否か考える，成形機の出力は，金型 の成形品の投影面積に必要とされる成形圧力を掛けたもの で算出され，成形機の最大出力の $80 \%$ 以下になるよう選 択する．圧縮成形では室温の練りゴムを仕込むため加硫中 に熱膨張による成形機への負荷が増加する．熱板の平行度 は断熱材やタイバーの熱膨張の影響を受け，さらにスライ ドする金型取り付け板と熱板の間の污れも平行度に影響す る．熱板の温度分布が均一であることは必要であるが，表 面温度計で測定しても正確な值は得られないようである。 せめて金型の搭載される部分の温度差は $2{ }^{\circ} \mathrm{C}$ 程度が好まし い. 加熱能力として成形品の取り出しー練りゴム仕込みの サイクル時の金型温度低下を短時間で回復していることを 確認する．金型温度低下が回復していない場合，加硫不足 の原因となることがある。

\section{2 練りゴム}

圧縮成形において金型に仕込む練りゴムは環境温度に等 しいので，金型成形の初期流動には季節による差がでるこ とがある。このような場合には作業手順を見直すことも必 要となる。また，練りゴムの再練り加工により粘度が低下 し，粘着性や加硫速度に変化が生じるので新しい練りゴム への混合比率も不良品防止上注意しなければならない。練 りゴムの保管においてスコーチを懸念して低温にした場

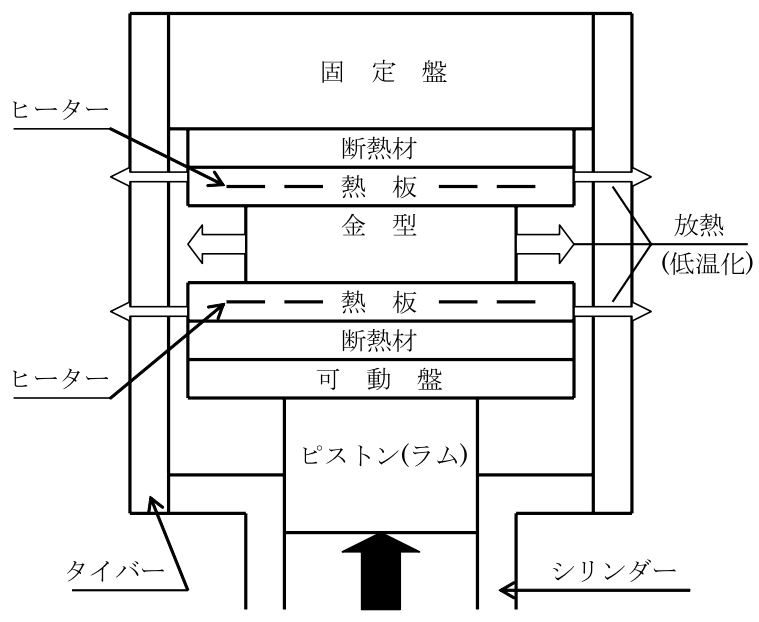

成形圧力 (ゲージ圧力)

図 9 成形機と放熱 
合，作業現場に持ち出した時に練りゴム表面に結露による 水滴が付着することがある，スコーチ，金型污れの促進と なり，配合によっては加硫後の劣化状態が変わるので，布 などで外面を覆い練りゴム表面に直接結露させないように する。

\section{3 金型への仕込み}

練りゴムの金型への仕込み方はキャビティの形状，個取 り数により異なる．練りゴムの流れ方は高圧部(練りゴム に成形圧力が最初にかかる部分) から低圧部に流れ，変形 のし易い部分から流れる．単純な形状として立方体を考え ると，上下面に荷重がかかると側面の自由表面がせり出す がコーナー部の変形は遅れる。この遅れ部分が融合部とな ることもある.また，食い切り構造の金型ではキャビティ 内部から練りゴムが流出するような仕込み方をしないとシ ヨートショット(充てん不足) となり易い. 要点はキャビテ イに均一に流れ込む状態に配置することである.

\section{5. 加硫後の問題 ${ }^{1,2)}$}

\section{1 表面の問題}

金型成形において練りゴムは極めて小さい隙間にも流入 し薄いばりを発生する。この薄いばりが成形品の表面に張 り付くと容易には取れない。高温で鏡面に付着した場合に は接着に近い状態となる。金型の分割面 (パーティング部) の摩耗や変形に注意する。加硫直後の高温の成形品同士を 接触させると，相互に密着し界面が融合するようになるこ とがある．この状態で泠却した後引きはがすと，密着面が 最悪の場合に凝集破壊のような状態となることがある。加 硫製品は安全な低温状態に冷却してから重ねるようにす る. 製品の積み重ねや保管も同様に高温となる状態を避け る.この加硫後に生じる問題を，表 5 にまとめてみた.

\section{2 ブルーム, ブリード現象}

配合設計時に考慮されているので現場として対策はな い.ブルーム現象は加硫剤に関係することが多く，成形加

表 5 加硫後の問題 1,2$)$

\begin{tabular}{|c|c|c|}
\hline 題 & 内 & 原因と考えられること \\
\hline \multirow[t]{2}{*}{ 1. 表面の問題 } & 薄いばりの表面付着 & 加硫直後に付着 \\
\hline & 成形品の表面の付着跡 & 加硫直後の密着 \\
\hline 2. ブルーム & \begin{tabular}{|l} 
加硫製品の表面の \\
粉吹き現象
\end{tabular} & $\begin{array}{l}\cdot \text { 加硫不足 } \\
\cdot \text { 揮発物の表面への付着 } \\
\cdot \text { 加硫直後の急冷 } \\
\cdot \text { 非相溶物質の偏在 }\end{array}$ \\
\hline 3. ブリード & $\begin{array}{l}\text { 加硫製品の表面に } \\
\text { 液状物質のにじみ出し }\end{array}$ & $\begin{array}{l}\text { ・軟化剤の不適 } \\
\text { ・防着剤などの影響 } \\
\text { ・加硫による極性の変化 }\end{array}$ \\
\hline 4. 変色 & 色物製品の変色 & $\begin{array}{l}\cdot \text { 加硫温度の影響 } \\
\cdot \text { 加硫後の保管の問題 }\end{array}$ \\
\hline 5. 劣化 & 劣化速度の促進 & $\begin{array}{l}\cdot \text { 加硫条件の変動 } \\
\cdot \text { 後加硫の影響 } \\
\cdot \text { 二次加硫の影響 } \\
\cdot \text { 加硫後の保管の問題 }\end{array}$ \\
\hline
\end{tabular}

硫の現場としては加硫不足が考えられるので加硫条件 (温 度，時間)の確認が必要となる，昇華性の配合剤がある場 合は加硫後冷却するまで開放状態を維持する。ブルーム, ブリード物質は配合上の問題でやむをえないことである が，製品と接触する他の部材への影響がある場合があるの で関係者に確認をする必要がある。

\section{3 変色}

変色は色物製品で見られるが，顔料の選択や混練におけ る顔料の分散による色調の違いの方が問題としては大き い. 成形現場としては変色に関係すると思われることに加 硫温度と加硫時間がある. 熱による顔料の変色やベースと なる練りゴムの色変わりが原因と思われるので加硫条件を 確認する。その他，金型からの離型性が関係する表面の状 態の差が変色といわれることもある．黑色製品でも老化防 止剂の影響による変色ということもある，光の影響による ものらしいので保管方法に注意する。

\section{4 劣化への影響}

成形条件と劣化については，作業指示条件を守っていれ ば関係ないと思われる。ただ，加硫後高温から室温に冷却 するまでの時間に生じる後加硫状態，二次加硫の場合の高 温からの冷却時間など, 加硫条件以外の高温暴露状態の影 響が成形品表面の劣化に関与することも考えられる.

\section{6.お わりに}

プレス機を用いた圧縮成形における不良品発生の原因と 関連する問題をまとめてみた。金型成形では練りゴムの流 動性が重要で，混練状態や予備成形の状態，練りゴムの温 度依存性の影響や加硫速度を把握しておくことが必要と思 う。また，練りゴムの金型内の流れ方を想定することが不 良対策の助けとなる．製造現場では経験上のひらめきも大 切である．射出成形と比較して練りゴムの流し方が特定で きないので不十分とのご批判もあることと思うが，少しで も参考になればよいと思う。

\section{References}

1) Nippon Gomu Kyokai Kanagata Kenkyu Bunkakai Ed.: "Gomuelastomer You Kanagata Gijutsu”, Kogyo Chosakai, Tokyo, p.239 (2004)

2 ) Kanagata Kenkyu Bunkakai: Nippon Gomu Kyokai Dai 148 Kai Gomugijutsu Symposium Text, p.69 (2008)

\section{日本語表記参考文献}

1）日本ゴム協会金型研究分科会編：ゴム・エラストマー用金型技 術, 工業調查会, 東京, p.239 (2004)

2 ）金型研究分科会：日本ゴム協会 第148回ゴム技術シンポジウ ム テキスト, p.69 (2008) 